\title{
Sistem Pakar Mendeteksi Penyakit Tanaman Kentang Dengan Metode Bayes
}

\author{
Lolita Lumban Gaol${ }^{1}$, Murni Marbun² \\ ${ }^{1,2}$ STMIK Pelita Nusantara, Teknik Informatika, Indonesia \\ lolitaleo93@gmail.com¹, dimploflorence@yahoo.co.id²
}

\begin{abstract}
Abstrak
Salah satu faktor yang mempengaruhi kualitas dan kuantitas kentang yang belum memadai adalah banyaknya penyakit pada tanaman kentang yang dapat menurunkan kualitas maupun kuantitas kentang. Salah satu cara untuk mendeteksi penyakit pada tanaman kentang dengan memanfaatkan perkembangan teknologi dan informasi yaitu dengan mengembangkan ilmu kecerdasan buatan (Artificial Intteligence), Sistem pakar yang dibangun ini mampu mendeteksi delapan jenis penyakit yang terdapat pada tanaman kentang. Penyakit yang dapat dideteksi antara lain penyakit layu bakteri, layu fusarium, bercak daun alternaria, busuk phytopthora, penyakit akibat virus penggulung daun, penyakit akibat virus $y$, dan penyakit akibat virus $x$. Hasil deteksi penyakit kentang adalah berupa jenis penyakit, nilai persentase penyakit, beserta solusi yang ditawarkan oleh sistem pakar. Sistem pakar ini dibangun dengan menerapkan atau mengaplikasikan metode bayes pada proses perhitungannya. Metode bayes merupakan salah satu metode yang terdapat pada sistem pakar yang dapat menghitung atau mengolah nilai-nilai probabililitas setiap gejala, yang dihitung menggunakan Formula Bayes sehingga menghasilkan kesimpulan berupa jenis penyakit dan nilai persentase dari setiap penyakit. Dari gejala yang diinput pada studi kasus ada tiga yaitu, G1, G2, G3, dengan nilai masing-masing adalah 0.9, 0.6,.dan 0.8, maka setelah diproses oleh sistem yang dibangun maka penyakit yang muncul adalah penyakit layu bakteri dengan nilai persentase $80.497 \%$.
\end{abstract}

Keywords - potato disease, expert system, bayes method

\section{Latar Belakang}

Bagian Kentang merupakan salah satu bahan pokok yang dapat diolah kedalam berbagai olahan makanan. Kentang berada pada peringkat ketiga bahan pokok yang dikonsumsi masyarakat dunia setelah beras dan gandum (International Potato Center, 2013). Namun dalam kenyataannya, produksi kentang dalam negeri belum mampu mencukupi kebutuhan pangan. Hal ini terlihat berdasarkan data dari Badan Pusat Statistik (BPS), Indonesia memang mengimpor kentang dari 5 negara yaitu Jerman, Kanada, Australia, Inggris dan Perancis dalam kurun waktu Januari-November $2016 * 1+$. Selain itu, masih banyaknya petani yang belum mengetahui berbagai jenis penyakit yang dapat menyerang tanaman kentang atau tingkat pengetahuan petani tentang penyakit pada tanaman kentang belum merata. Hal ini disebabkan karena kurangnya informasi tentang penyakit-penyakit pada tanaman kentang yang dapat diterima oleh petani. Sistem pakar adalah salah satu sistem yang telah terkomputerisasi yang dapat membantu mendeteksi penyakit pada tanaman kentang yang diharapkan mampu membantu para petani kentang dalam mengenali berbagai penyakit pada tanaman kentang berdasarkan gejala-gejala yang muncul pada tanaman kentang. Metode bayes adalah salah satu pendekatan untuk sebuah ketidaktentuan yang diukur dengan probabilitas atau kemungkinan *2+. Metode bayes dipilih dalam perancangan sistem pakar mendeteksi penyakit pada tanaman kentang karena pada metode bayes, dibutuhkan informasi-informasi dalam bentuk nilai probabilitas untuk setiap alternatif yang ada pada persoalan yang sedang dihadapi yang nantinya akan menghasilkan nilai harapan sebagai dasar pengambilan keputusan $* 3+$.

\section{Metode Sistem Pakar}

Sistem pakar adalah program kecerdasan buatan yang menggabungkan pangkalan pengetahuan base dengan sistem inferensi untuk menirukan seorang pakar [4].

Program Studi Teknik Informatika

Universitas Prima Indonesia (UNPRI) Medan 
Sistem pakar merupakan sistem yang berusaha

mengadopsi pengetahuan manusia ke komputer, agar komputer dapat menyelesaikan masalah seperti yang biasa dilakukan oleh para ahli. Diharapkan dengan sistem pakar ini, pengguna dapat menyelesaikan masalah tertentu, tanpa bantuan para ahli dalam bidang tersebut. Suatu sistem pakar adalah suatu sistem komputer yang menyamai (emulates) kemampuan pengambilan keputusan dari seorang pakar. Istilah emulates berarti berarti sistem pakar diharapkan dapat bekerja dalam semua hal seperti seorang pakar [5]. Suatu emulasi jauh lebih kuat daripada suatu simulasi yang hanya membutuhkan sesuatu yang bersifat nyata dalam beberapa bidang atau hal. Bagian dari sistem pakar adalah terdiri dari 2 komponen utama yaitu knowledge base yang berisi knowledge dan inferensi yang menggambarkan kesimpulan. diusulkan, dataset yang digunakan, analisa dan tahapan pengujian metode. Kesimpulan tersebut merupakan respons dari sistem pakar atau permintaan pengguna [6], [7].

\section{Probabilitas Bayes}

Probabilitas bayes merupakan salah satu cara yang baik untuk mengatasi ketidakpastian data dengan menggunakan formula bayes yang dinyatakan dengan rumus sebagai berikut [8]:

$\mathrm{P}(\mathrm{A} \mid \mathrm{B}) \quad \mathrm{P}(\mathrm{B} \mid \mathrm{A}) * \mathrm{P}(\mathrm{A})$

$P(A \mid B)$ : probabilitas $A$ dan $B$ terjadi bersama-sama

$P(B \mid A)$ : probabilitas $B$ dan A terjadi bersama-sama

$P(B)$ : probabilitas kejadian $B$

Langkah-langkah dalam menerapkan metode bayes dalam sistem pakar adalah menginput gejala-gejala yang diketahui oleh user, kemudian mencari nilai semesta dengan menjumlahkan probabilitas dari masing-masing gejala yang dialami atau dapat diformulasikan dengan rumus berikut :

$$
\begin{aligned}
& \sum_{i=1}^{n} \mathrm{P}(\mathrm{E} \mid \mathrm{H} 1)+\mathrm{P}(\mathrm{E} \mid \mathrm{H} 2)+ \\
& +\mathrm{P}(\mathrm{E} \mid \mathrm{Hn}) \quad \text {...................(2)hitung nilai probabilitas }
\end{aligned}
$$

hipotesis $\mathrm{H}$ tanpa memandang gejala/evidence apapun

yaitu sebagai berikut:

$$
\mathrm{P}(\mathrm{Hi})=\frac{\mathrm{P}(\mathrm{E} \mid \mathrm{Hi})}{\sum_{i=1}^{n}(P(E \mid H i)}
$$

Setelah mengetahui hasil dari $\mathrm{P}(\mathrm{Hi})$ atau probabilitas hipotesis tanpa memandang gejala apapun, kemudian langkah selanjutnya adalah menghitung nilai probabilitas evidence E dengan rumus sebagai berikut:

$$
\begin{aligned}
& \mathrm{P}(\mathrm{E})= \\
& \sum n
\end{aligned}
$$

Setelah mendapat nilai dari probabilitas evidence $E$, maka langkah selanjutnya adalah menghitung nilai bayes setiap hipotesis dengan rumus sebagai berikut:

$\mathrm{P}(\mathrm{Hi} \mid \mathrm{E})=\underline{\mathrm{P}(\mathrm{E} \mid \mathrm{Hi}) * \mathrm{P}(\mathrm{Hi})}$

$$
\mathrm{P}(\mathrm{E})
$$

Setelah mendapatkan seluruh nilai dari $\mathrm{P}$ ( $\mathrm{Hi} \mid \mathrm{E})$, maka langkah selanjutnya adalah menghitung total nilai bayes dengan rumus sebagai berikut:

$\sum_{n=1}^{n}$ Bayes $i$ Bayes $1+$ Bayes $2+$

Bayes $n$

langkah terakhir adalah menghitung persentase dari Total Nilai Bayes dengan rumus:

sebagai berikut:

Persentase $=\quad \sum_{i=1}^{n}$ Bayes $i * 100 \%$

\section{Penyakit Pada Tanaman Kentang}

Penyakit pada tanaman kentang ada yang disebabkan oleh bakteri, virus, maupun cendawan. Beberapa penyakit yang terdapat pada tanaman kentang:

a. Penyakit Layu Bakteri. Penyakit layu bakteri adalah penyakit yang disebabkan oleh bakteri Ralstonia Solanaceraum. Gejala biasanya diawali dengan pucuk atau titik tumbuh layu.

b. Layu Fusarium. Layu fusarium adalah penyakit pada tanaman kentang yang disebabkan oleh cendawan Fusarium oxysporum. Gejala biasanya ditandai dengan tanaman tiba-tiba layu.

c. Penyakit busuk daun kentang atau busuk Phytopthora Infestans. Penyakit ini disebabkan oleh cendawan Phytopthora infestans. Gejala ditandai dengan adanya bercak-bercak pada daun.

d. Penyakit bercak alternaria/bercak kering Penyakit ini disebabkan oleh cendawan alternaria sp. Gejala ditandai dengan adanya bercak-bercak cokelat pada daun.

e. Penyakit akibat virus penggulung daun. Penyakit ini disebabkan oleh potato leaf roll virus.

f. Penyakit akibat virus Y. Penyakit ini disebabkan oleh virus Y. Gejala ditandai dengan adanya belang-belang pada daun.

g. Penyakit akibat virus $X$. Penyakit ini disebakan oeh virus $x$ yang ditandai dengan adanya belang-belang berwarna kuning pada daun.

h. Penyakit akibat virus $\mathrm{S}$

Penyakit ini disebabkan oleh virus $S$ yang ditandai dengan munculnya belang-belang pada daun berwarna kuning pucat.

\section{Hasil}

\section{Analisis Data}


Studi kasus yang dibahas dalam penelitian ini, berbagai gejala yang muncul pada tanaman kentang akan dihitung menggunakan rumus atau ketentuan pada metode bayes untuk menarik kesimpulan tentang penyakit pada tanaman kentang tersebut.

1. Tabel Gejala

Tabel gejala merupakan tabel yang berisi gejala penyakit pada tanaman kentang. Tabel gejala terdiri dari kode gejala, gejala, dan nilai probabilitas bayes, Tabel 1 . Tabel 1. Tabel Data Gejala

\begin{tabular}{|c|c|c|}
\hline $\begin{array}{l}\text { Kode } \\
\text { Gejala }\end{array}$ & Gejala & $\begin{array}{l}\text { Nilai } \\
\text { Probabilitas } \\
\text { Bayes }\end{array}$ \\
\hline G1 & Pucuk/titik tumbuh layu & 0.9 \\
\hline $\mathrm{G} 2$ & $\begin{array}{l}\text { Titik tumbuh yang layu menjalar ke batang } \\
\text { dan daun yang sudah tua hingga akar }\end{array}$ & 0.6 \\
\hline G3 & Seluruh tanaman/rumpun tanaman layu & 0.8 \\
\hline G4 & Tanaman tiba-tiba layu & 0.6 \\
\hline G5 & $\begin{array}{l}\text { Tanaman terlihat layu sebagian (sebagian } \\
\text { rumpun layu) }\end{array}$ & 0.9 \\
\hline G6 & Layu dimulai dari bawah & 0.6 \\
\hline G7 & Tulang daun berwarna kuning & 0.6 \\
\hline G8 & $\begin{array}{l}\text { Jika batang dibelah, jaringan batang daun } \\
\text { berwarna cokelat }\end{array}$ & 0.8 \\
\hline G9 & Tanaman mengering & 0.8 \\
\hline G10 & $\begin{array}{l}\text { Terdapat bercak-bercak pada daun bagian } \\
\text { tengah dan tepi }\end{array}$ & 0.8 \\
\hline G11 & $\begin{array}{l}\text { Bercak-bercak melebar, bulat berwarna } \\
\text { cokelat atau hitam }\end{array}$ & 0.6 \\
\hline G12 & $\begin{array}{l}\text { Serangan menyebar kebatang, tangkai dan } \\
\text { umbi }\end{array}$ & 0.5 \\
\hline G13 & Serangan dimulai pada daun yang tua & 0.8 \\
\hline G14 & Serangan menyebar ke daun yang muda & 0.6 \\
\hline G15 & Daun mengering dan gugur & 0.4 \\
\hline G16 & $\begin{array}{l}\text { Tepi daun menggulung dari arah tangkai } \\
\text { daun ke atas dan lebih tegak dari daun yang } \\
\text { sehat }\end{array}$ & 0.8 \\
\hline G17 & Daun kaku & 0.8 \\
\hline G18 & Daun mudah dipatahkan & 0.6 \\
\hline G19 & Timbul belang-belang pada daun & 0.7 \\
\hline G20 & Pertumbuhan terlambat & 0.6 \\
\hline G21 & Tulang daun menggulung & 0.8 \\
\hline G22 & $\begin{array}{l}\text { Terlihat garis cokelat pada batang dan } \\
\text { tangkai daun }\end{array}$ & 0.5 \\
\hline G23 & Daun mudah gugur & 0.6 \\
\hline G24 & $\begin{array}{l}\text { Muncul belang-belang pada daun berwarna } \\
\text { kuning pucat diantara tulang daun }\end{array}$ & 0.5 \\
\hline G25 & Tulang daun terlihat tenggelam & 0.5 \\
\hline G26 & $\begin{array}{l}\text { Permukaan daun tidak rata atau terlihat } \\
\text { menonjol }\end{array}$ & 0.5 \\
\hline G27 & Warna antara tulang dan daun berbeda & 0.8 \\
\hline
\end{tabular}

\section{Tabel Rule}

Kaidah aturan atau rule base merupakan aturan yang bertujuan untuk menghubungkan gejala dengan penyakit yang terdapat pada tanaman kentang. Rule base ini bertujuan untuk menarik kesimpulan tentang penyakit yang ada pada tanaman kentang. Berikut adalah tabel rule base dalam penentuan jenis penyakit pada tanaman kentang, Tabel 2.

Tabel 2

Tabel Rule Base

\begin{tabular}{lll}
\hline Rule Gejala Jenis Penyakit &
\end{tabular}

IF pucuk/titik tumbuh layu is true

AND titik tumbuh yang layu menjalar ke

Rule batang dan daun yang sudah tua hingga akar

1 is true

Layu Bakteri

AND seluruh tanaman/rumpun tanaman

layu is true THEN Layu Bakteri

IF tanaman tiba-tiba layu is true AND tanaman terlihat layu sebagian

(sebagian rumpun layu) is true

Rule AND tulang daun berwarna kuning is true

2 AND jika batang dibelah, jaringan batang daun berwarna cokelat is true

Layu Fusarium

AND anaman mengering is true THEN Layu Fusarium

IF terdapat bercak-bercak pada daun bagian tengah dan tepi is true

Rule AND bercak-bercak melebar, bulat berwarna

3 cokelat atau hitam is true

AND serangan menyebar kebatang, tangkai dan umbi is true

AND serangan dimulai pada daun yang tua is

atau Busuk

Phytopthoro true THEN Busuk daun atau Busuk

Phytopthora

IF terdapat bercak-bercak pada daun bagian

tengah dan tepi is true

AND serangan dimulai pada daun yang tua is

Rule true muda is true

AND daun mengering dan gugur is true

THEN Bercak daun Alternaria

IF tepi daun menggulung dari arah tangkai

daun ke atas dan lebih tegak dari daun yang

Rule sehat is true

5 AND daun kaku is true

AND daun mudah dipatahkanis true THEN

Bercak daun

Alternaria

Penyakit akibat Virus penggulung daun

IF timbul belang-belang pada daun is true

AND pertumbuhan terlambat is true

Rule AND tulang daun menggulung is true

6 AND terlihat garis cokelat pada batang dan

Penvakit

6 tangkai daun is true

Akibat Virus $Y$

AND daun mudah gugur is true THEN

Penyakit akibat Virus $Y$

IF muncul belang-belang pada daun

berwarna kunıng pucat diantara tulang daun

is true

Rule AND tulang daun terlihat tenggelam is true Penyakit akibat

7 ANPpgermukaan daun tidak rata atau

AND warna antara tulang dan daun berbeda is true THEN Penyakit akibat Virus $\mathrm{X}$

IF tulang daun terlihat tenggelam is true

AND permukaan daun tidak rata atau

Rule terlihat menonjol is true

Penyakit akibat

AND warna antara tulang dan daun berbeda

Virus S

is true THEN Penyakit akibat virusS

\section{Studi Kasus}

Program Studi Teknik Informatika

Universitas Prima Indonesia (UNPRI) Medan 
Diketahui: Seorang user menginput G1 (pucuk/titik tumbuh layu), G2 (titik tumbuh yang layu menjalar ke batang dan daun yang sudah tua hingga akar), dan G3 (seluruh rumpun tanaman layu). Penyakit apakah yang menyerang tanaman kentang berdasarkan gejala tersebut dan berapakah nilai probabilitas bayesnya?

Nilai probabilitas gejala $\mathrm{G} 1=0.9=\mathrm{P}(\mathrm{E} \mid \mathrm{H} 1), \mathrm{G} 2=$ $0.6=P(E \mid H 2), G 3=0.8=P(E \mid H 3)$

Penyelesaian:

1. Mencari semesta dengan menjumlahkan probabilitas tiap-tiap gejala :

$$
\sum_{n=1}^{3} \quad \mathbf{G} \mathbf{1}+\mathbf{G} \mathbf{2}+\mathbf{G} \mathbf{3}=0.9+0.6+0 .=2.3
$$

2. Menghitung nilai probabilitas $\mathrm{H}$ tanpa memandang evidenve apapun :

$$
\begin{aligned}
& P(H 1)=\frac{P(E \mid H 1)}{\sum_{i=1}^{n}(P(E \mid H 1)}=0.3913 \\
& P(H 2)=\frac{P(E \mid H 2)=0.2608}{\sum_{i=1}^{n}(P(E \mid H 2)}=0.3478 \\
& P(H 3)=\frac{P(E \mid H 3)}{\sum_{i=1}^{n}(P(E \mid H 3)}
\end{aligned}
$$

3. Menghitung probabilitas evidence $E$

3

$$
\begin{array}{rl}
\sum_{k=1} & P(H i) * P(E \mid H i) \\
= & P(H 1) * P(E \mid H 1)+P(H 2) * P(E \mid H 2)+ \\
& P(H 3) * P(E \mid H 3) \\
= & 0.3913 * 0.9+0.2608 * 0.6+0.3478 * 0.8 \\
= & 0.7863
\end{array}
$$

3. Menghitung nilai bayes setiap hipotesis

$$
\begin{aligned}
& P(H 1 \mid E)=\frac{0.9^{*} 0.3913}{0.7863}=0.4478 \\
& P(H 2 \mid E)=\frac{0.6^{*} 0.2608}{0.7863}=0.1990 \\
& P(H 1 \mid E)=\frac{0.8^{*} 0.3478}{0.7863}=0.3538
\end{aligned}
$$

5. Setelah mendapatkan seluruh nilai bayes, maka langkah selanjutnya adalah menghitung total nilaibayes

$$
\begin{aligned}
& =0.9 * 0.4478+0.6 * 0.1990+0.8 * 0.3538 \\
& =0.40302+0.1994+0.28304 \\
& =0.8054
\end{aligned}
$$

6. Langkah terakhir adalah menghitung nilai persentase dari total nilai bayes yaitu :

$$
=0.8054 * 100 \%
$$

$=80.54 \%$ (Kemungkinan besar penyakit layu bakteri)

\section{Menu Aplikasi}

Menu adalah bagian yang berisi tentang data gejala, data penyakit, dan data rule yang hanya dapat diakses oleh developer sistem, Gambar1.

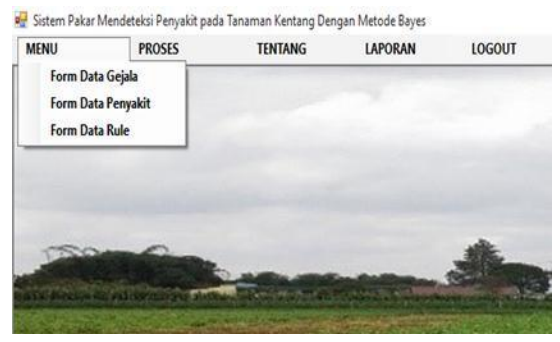

Gambar 1. Menu Aplikasi

Form data penyakit terdiri dari form yang berisi 8 jenis penyakit pada tanaman kentang Gambar 2.

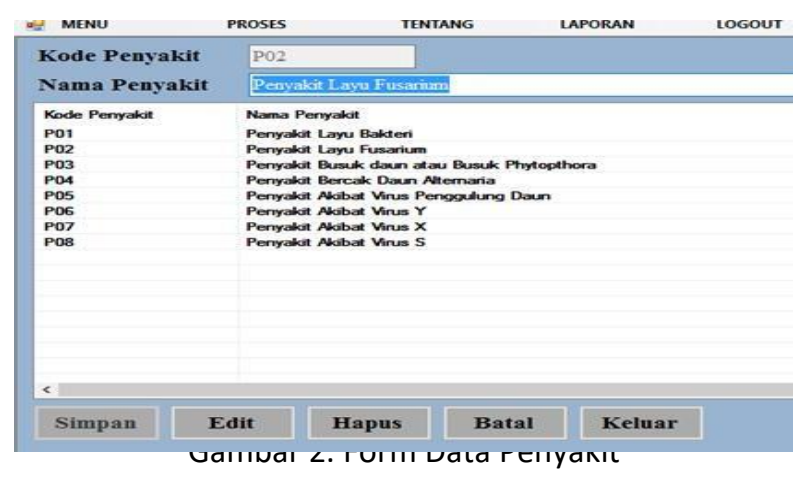

Form data gejala adalah form yang berisi tentang 27 gejala yang ada pada delapan jenis penyakit tanaman kentang Gambar 3. 
Publikasi Jurnal Penelitian Teknik Informatika Universitas Prima Indonesia (UNPRI) Medan
Volume 1 Nomor 2, Oktober 2018 e-ISSN : 2621-234X

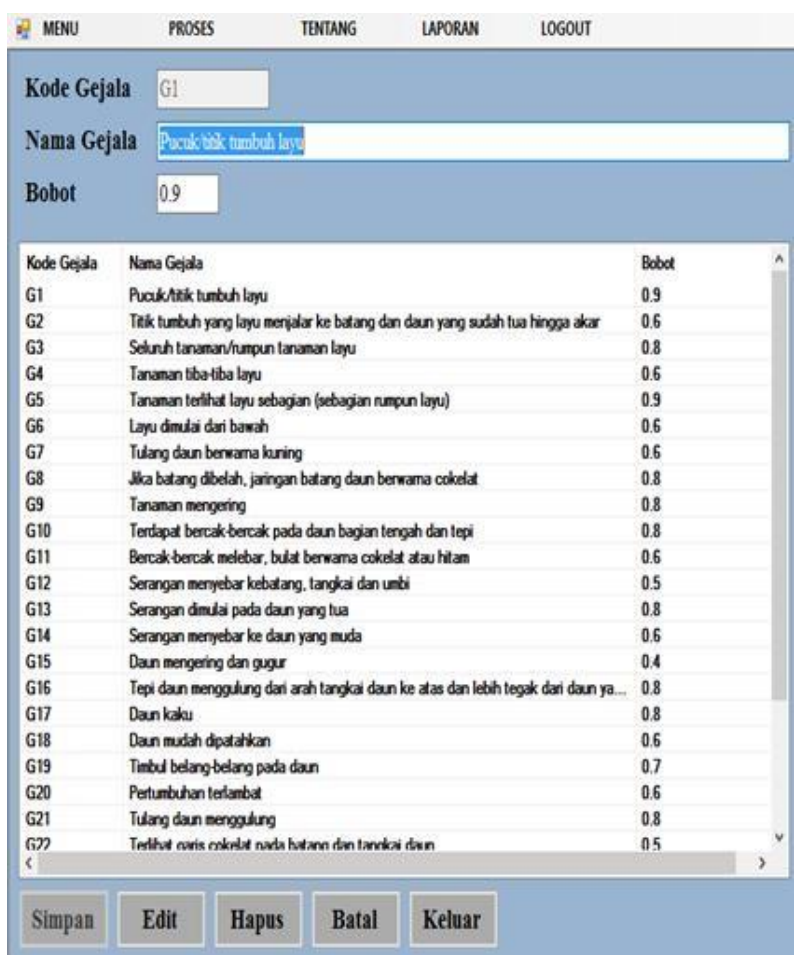

Gambar 3. Form Data Gejala

Halaman konsultasi merupakan halaman dimana user melakukan konsultasi dalam sistem Gambar 4.

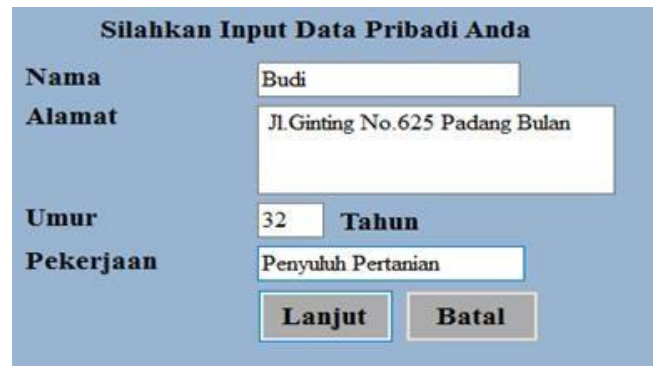

Gambar 4. Form Input Data Konsultasi Setelah penginputan data diperoleh hasil konsultasi Gambar 5.

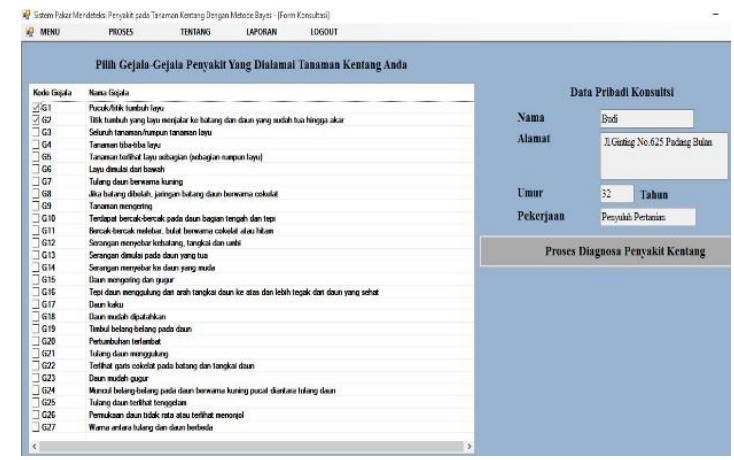

Gambar 5. Form Konsultasi

Form hasil konsultasi adalah form yang berisi hasil pengolahan gejala-gejala, yang diproses dengan metode bayes dan menghasilkan kesimpulan tentang jenis penyakit, persentase penyakit tersebut, penyebab, dan solusi dari penyakit tersebut Gambar 6 .

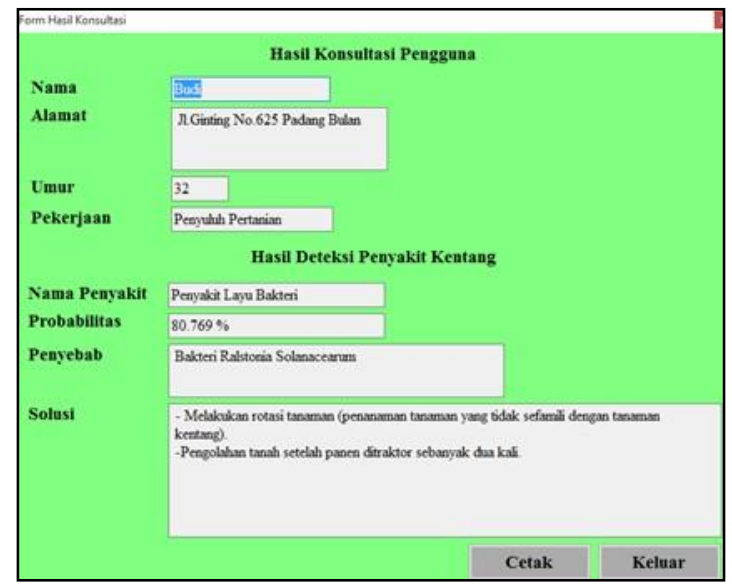

Gambar 6. Form Hasil Konsultasi

Hasil

Jika gejala yang diinput ada tiga yaitu, G1, G2, G3, dengan nilai masing-masing adalah 0.9, 0.6,.dan 0.8, maka setelah diproses oleh sistem yang dibangun maka penyakit yang muncul adalah penyakit layu bakteri dengan nilai persentase $80.497 \%$. Hasil tersebut sesuai dengan perhitungan secara manual yang dilakukan oleh peneliti. Hasil perhitungan manual, Gambar 7.

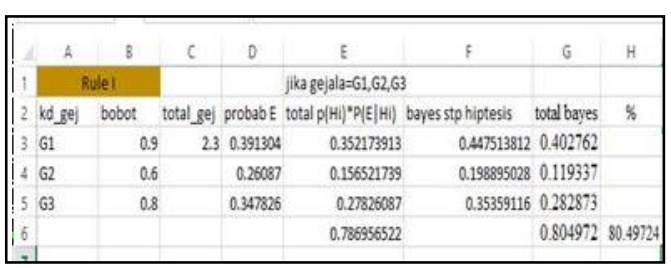

Gambar 7. Hasil Perhitungan Manual Hasil perhitungan manual dengan perhitungan dengan yang ada di dalam sistem pakar mendeteksi penyakit pada tanaman kentang dengan metode bayes, Gambar 8

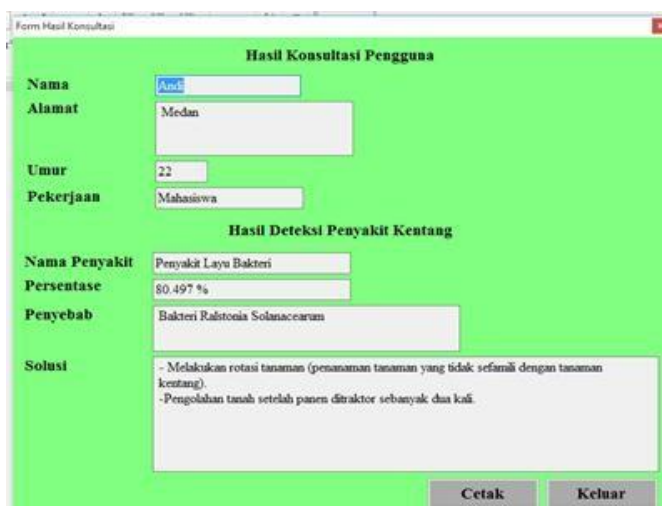

Gambar 8. Hasil Akhir Perhitungan Metode Bayes

Program Studi Teknik Informatika

Universitas Prima Indonesia (UNPRI) Medan 


\section{Kesimpulan}

1. Menurut Pakar ada 27 (dua puluh tujuh) gejala yang ada pada tanaman kentang dan 8 (delapan jenis penyakit antara lain: Penyakit Layu Bakteri, Layu Fusarium, Penyakit busuk daun kentang atau busuk Phytopthora Infestans, Penyakit bercak alternaria/bercak kering, Penyakit akibat virus $Y$, Penyakit akibat virus $X$, Penyakit akibat virus S).

2. Sesuai Metode Bayes pada sistem pakar, penyakit tanaman kentang dapat dideteksi pada form hasil konsultasi yaitu form yang berisi hasil pengolahan gejala-gejala, yang diproses dengan metode bayes dan menghasilkan kesimpulan tentang jenis penyakit, persentase penyakit tersebut, penyebab, dan solusi dari penyakit tersebut.

3. Terdapat perbedaan perhitungan manual dengan sistem yang dibangun dengan menggunakan Metode Bayes, diinput ada tiga yaitu, G1, G2, G3, dengan nilai masing-masing adalah 0.9, 0.6,.dan 0.8, maka setelah diproses oleh sistem yang dibangun maka penyakit yang muncul adalah penyakit layu bakteri dengan nilai persentase $80.497 \%$.

4. Kelemahan dari sistem informasi kepakaran mendeteksi penyakit tanaman kentang adalah jumlah dan gejala penyakit dbatasi pada penginputan data.

\section{Ucapan terima kasih}

Ucapan terima kasih pada seluruh Civitas Penusa Medan dan Independent Researcher ASST.

\section{References}

[1] Monica Wenas, Guntur S.J. Manengkey, Henny V.G. Makal, "Insidensi Penyakit Layu Bakteri Pada Tanaman Kentang (Solanum Tuberosum L) Di Kecamatan Modoinding", VOL 7, NO 3, 2016.

[2] SINAGA, Anita Sindar RM. bayes Diagnosa Penyakit Ikan Hias Air Tawar Dengan Teorema Bayes. SinkrOn, [S.I.], v. 3, n. 1, p. 43-50, Sep. 2018

[3] Barus, Verawaty Monica, Mesran, Suginam, "Sistem Pakar Untuk Mendiagnosis Hama Pada Tanaman Jambu Biji Menggunakan Metode Bayes", Jurnal INFOTEK, 2 (1), hal: 78-81, Februari 2017.

[4] Hartatik., Yasa, Ketut Putra I, "Sistem Pakar Untuk Mendeteksi Hama Tanaman Jahe Menggunakan Teorema Bayes", Jurnal IImiah DASI, 16 (02), Juni 2015.

[5] Sihotang, Tamando Hengki., Panggabean, Erwin., \& Zebua, Herlina, " Sistem Pakar Mendiagnosa Penyakit Herpes Zoster dengan Menggunakan Metode Teorema Bayes", Journal Of Informatic
Pelita Nusantara, 3 (1), Maret 2018.

[6] Barus, Verawaty Monica, Mesran, Suginam, "Sistem Pakar Untuk Mendiagnosis Hama Pada Tanaman Jambu Biji Menggunakan Metode Bayes", Jurnal INFOTEK, 2 (1), hal: 78-81, Februari 2017.

[7] Mahmudi, Ali., Rokhman, Moh. Miftakhur., Prasetio, Ahmad Eko, "Rancang Bangun Sistem Pakar Untuk Mendiagnosis Tanaman Cabai Menggunakan Metode Baye", Jurnal Rekayasa dan Manajemen Sistem Informasi, 2 (2), Agustus 2016.

[8] Ria Andriani, Burhanudin Dwi Prakoso, -Sistem Pakar Diagnosa Penyakit Hyperopia dan Myopia Pada Manusia Berbasis Android Mengguanakan Teorema Bayes, Seminar Nasional Teknologi Informasi dan Multimedia 2016, hal 6-13, Februari 2016 